\title{
Analyzing the Emotional Bondage of Serial Fans and Business Decisions on Series Extension in the Context of the Impact on the Stock Price of the Providers
}

\author{
Dennis Schmidt ${ }^{1}$, Alexander Zureck ${ }^{2}$, Stefanie Gradetzki ${ }^{3}$, Gennadij Seel ${ }^{4}$ \\ ${ }^{1}$ Masaryk University / FOM University of Applied Sciences \\ Department of Finance at Faculty of Economics and Administration \\ Herkulesstraße 32, 45127 Essen, Germany \\ E-mail: dennisxschmidt@web.de \\ ${ }^{2}$ FOM University of Applied Sciences \\ Department of Finance at Faculty of Economics and Administration \\ Herkulesstraße 32, 45127 Essen, Germany \\ E-mail: alexander.zureck@email.de \\ ${ }^{3}$ FOM University of Applied Sciences \\ Department of Finance at Faculty of Economics and Administration \\ Herkulesstraße 32, 45127 Essen, Germany \\ E-mail: st.gradetzki@web.de \\ ${ }^{4}$ Masaryk University / FOM University of Applied Sciences \\ Department of Finance at Faculty of Economics and Administration \\ Herkulesstraße 32, 45127 Essen, Germany \\ E-mail: gennadij.seel@fom-net.de
}

\begin{abstract}
The desire of audiences to consume content in a series format, independent of time and place, has increased in recent years, helped by technological advancements. In this paper, series are considered goods sales of which are linked to the degree of viewers' attention. Thus, the good series operate on two interconnected levels, an economic and an emotional. The decision to invest in the production of another season of a series is motivated by an increase in the number of subscriptions and the associated revenues. Capital market participants are influenced by various emotional biases when making investment decisions under uncertainty. In the context of an event study, it is examined whether announcements of season extensions have a significant influence on the share price of the respective providers. The results show that investors react with a changed investment behavior. Furthermore, findings from the film industry are transferred to series production.
\end{abstract}

Keywords: quality-TV, movie business, streaming, behavioral finance, priming

JEL codes: G14, G32, G41 


\section{Introduction}

Over the past 35 years, the consumption behavior of audiovisual media has changed dramatically. In the 1980s, users were unable to determine the start and end of audiovisual media themselves. Due to the technical progress and the numerous streaming offers, today only an Internet connection is needed to consume audiovisual content. The recipients' desire to independently use offers from the entertainment sector has come to the fore (see Nitschke 2005, p.2 and Schlütz 2016, p.152). As a result, online distribution of media content, such as digitized series or cinema movies, is one of the growth markets with a massive impact on the traditional value chains of linear television. Because of a clear focus on the needs of consumers and an innovative pricing model, the series provider Netflix was able to grow rapidly and achieve great success. Currently, approx. $40 \%$ of Internet users in Germany watch films and series from paid providers (see bitkom 2018).

Each recipient has a feeling, a thought or a memory, which they associate with the consumption of television series. Recipients also know what they like about series and what they think is bad. Series are in the field of tension, because on the one hand, they are a sort of art, on the other hand, they are products that need to be refinanced. Therefore, the prerequisite is an emotional attachment of the recipients to the series (see Schlütz 2016, p.1-2).

Two research areas form the basis of this article. Previous research has investigated which series characteristics are decisive in order to classify them as quality series with a high emotional binding factor. In addition, there are several studies focusing on films as investment projects. These findings from the film industry will be transferred to series in the course of the investigations in this paper. The present study combines these two research directions and focuses on the connection between the economic and the behavioristic level in relation to series.

The central question of this study is whether the announcement to extend a series by another season influences the stock price of the respective provider. In addition, various subordinate goals are pursued. First, the evolution of a serial vision and the associated change in profit realization for multimedia and entertainment companies will be analyzed. In the process, a closer look is taken at new company fields which have arisen as a result of technical progress. The findings serve to understand how series suppliers are set up and how series are produced, marketed and distributed. Subsequently, series are examined for their characteristics and the associated effects on the recipients. The results are linked to the theoretical findings of Behavioral Finance.

This study analyzes whether there is an emotional connection between serial fans as investors and the entrepreneurial decision to produce another season series. It checks whether shareholders express their consent or rejection to the investment decision made by changing the shares they hold. Furthermore, it is examined 
whether a general behavior of shareholders can be derived based on this entrepreneurial decision.

\section{Literature Review and Hypotheses Development}

In order to concretize the research hypotheses, first, a review of empirical literature in this field is necessary.

Over the past 15 years, series have developed from a simple entertainment form to a product with a high-quality factor. This was due to technical innovations and the concomitant change in serial viewing. Therefore, this branch of research can be described as still very young. Movies are large investment projects with high production costs. Series can be assigned to a similar product group. Since films have a longer history in terms of production and marketing, this study will also take a closer look at films and their results.

DeVany and Walls analyzed the film industry in terms of its risk potential. For this purpose, films published between 1984 and 1996 were examined in 2015. Factors they used to analyze were production costs, genre, critiques, revenue, sales, and profits in the US and Canada using multiple linear regression. It was proven that earnings and profits are extremely skewed, fat-ended and have infinite variances. The reasoning is based on the fact that there is no typical film, as the box office results diverge across all values. Past successes still do not allow conclusions to be drawn on future successes, as the revenues do not have a convergent mean, but have an infinite variance across the entire results area. The success of a film cannot be attributed to individual causal factors. However, the recipient's opinion is the most important variable in determining the box office results. Consequently, forecasts of revenue and profits must be rejected. The final conclusion of this investigation is that the film industry has an extremely high risk potential, since the audience ultimately determines the success and failure of a film (see De Vany \& Walls 1999, pp. 26-29).

There are several studies that have looked into the acceptance and use of paid online video distribution offerings over free peer-to-peer file-sharing networks. Nitzschke empirically established the determining preferences of users and deduced their willingness to pay for films and series. Consumers must make their choice under uncertainty. You can choose between a free exchange, where the download time and the quality of the film/series are uncertain, and a paid provider, where these factors are known. Nitzschke used the Choice-Based Conjoint analysis to develop proposals for commercial vendors to influence consumer choice in their favor. He was able to quantify the effect of heuristic approach. Furthermore, he was able to prove that users are willing to pay the costs of a premium provider with a high relevance of the film/series. They bring the perceived value of the film/series with the value of the sales channel in a subjective harmony and try to hedge against psychological and economic risks. By empirically examining various effects of uncertainty on voting behavior in online video distribution, his study contributed to 
researching the market opportunities of commercial Video on Demand offerings (see Nitzschke 2005, pp.191-194).

Elberse used an event study to investigate whether casting roles with well-known and successful actors is critical to film success. The impact of 1200 announcements on the behavior of Hollywood Stock Exchange (HSX) participants was examined. The HSX is a popular online market simulation where players/retailers predict boxoffice takings. It was demonstrated that HSX prices are significantly responsive to stellar casting decisions. On average, each star cast is worth more than \$ 3 million in cinema revenue (see Elberse 2007, p.103 and p.112). However, the complex uniqueness of films makes it extremely difficult to sustainably validate hypotheses about success factors. Films and series have the common feature that both have a unique character. A perfect substitute cannot be created due to the specific manufacturing factors (for example, screenplay, director, actor) (see Dördrechter 2006, p.8). It is also questioned to what extent a statistical connection cannot be justified by the fact that the most successful actor can also choose the film with the best script. Furthermore, it was proved that the overall cast of the roles is decisive for the overall success of the film (see Elberse 2007, p.103 and p.113-115).

Einav and Ravid in a further event study examined whether the postponement of film launches has an impact on the stock price of the producing film studio. 302 changes by 25 different film studios were analyzed. There was evidence of negative abnormal significant returns. Market participants are skeptical of changes and new statements, even if they can be interpreted positively. Investors interpret this change as uncertainty about the progress of the project and classify such a message negatively. The abnormal returns on shifts to a date not yet specified were less negative than on actual new launch dates. Furthermore, it could be shown that the extent of the reaction of the stock market to the announcements is significantly related to the production costs of the film, but not to the later revenues of the film. This can be interpreted as a limited ability of the market to predict the future success of films. The results also show the importance of long-term publishing strategies of studios. Frequent schedule adjustments and an obscure movie bookkeeping lead the market to be skeptical about announced changes (see Einav \& Ravid 2009, pp.311-318).

Bock determined quality characteristics and analyzed which of them a series has to contain in order to be successfully marketed. With the help of a three-part empirical study, it was established based on which factors German listeners receive US primetime series. With the help of structured guideline interviews and online surveys, it was shown that the series with many links to the viewer's world of life without explicitly referring to actual problems are very popular. Furthermore, because of their ongoing storylines, series build a stronger audience bond than movies. Recipients have already begun to separate from linear television as a reception medium, as they want to decide themselves when they continue to follow the plot of the series. Recipients have a very high emotional attachment to a series that was once considered to be good (see Bock 2013, p.219-231). 
The study focuses on the three following hypotheses (see Table 1), which are tested respectively with the event study methodology.

Table 1 Research Hypotheses

\section{No. Hypothesis}

\begin{tabular}{ll}
\hline \hline H1 & $\begin{array}{l}\text { Seasonal extensions of a series have a significant impact on the return } \\
\text { performance of the respective provider. }\end{array}$ \\
\hline$H 2 \quad \begin{array}{l}\text { Shareholders respond to the announcement of staggered renewals with a reduction } \\
\text { in their stake. }\end{array}$ \\
\hline$H 3 \quad \begin{array}{l}\text { The announcement of the second season has a positive significant influence on the } \\
\text { yield development of the respective provider. }\end{array}$
\end{tabular}

Source: Authors' own representation.

\section{Empirical Analysis}

\subsection{Methodology}

The focus of this study lies on the critical analysis of stock prices of series suppliers. Investigations on the capital market offer the advantage that stock prices, in contrast to balance sheet or earnings ratios, cannot be optimized, even within the scope of the legal options. The influence of supply and demand is theoretically possible but requires an enormous capital investment. In the context of Behavioral Finance, courses continue to offer the advantage that certain reactions to behaviorinfluencing information can be seen directly in the course of the share price (Zureck, 2016).

From the information available, only the publication date of the press release, but not the exact date of the announcement of the season extension, can be determined. Therefore, for the present study, the returns are calculated on the basis of the daily closing prices.

The following return definitions are used in this event study:

The logarithmic returns are calculated, as these, in contrast to discrete returns, tend to be more normally distributed and more robust (Pauser, 2007).

$$
R_{i t}=\ln \left(P_{i t}\right)-\ln \left(P_{i t-}\right)
$$

The expected rate of return is defined as the rate of return that would have been expected without the occurrence of the event under investigation. The calculation of these results in the present study uses the market model. The market model assumes a linear relationship between the return on investment and the return on 
a market portfolio. The market model is thus a regression model. Using the leastsquares method, the parameters $\alpha_{i}$ and $\beta_{i}$ can be estimated efficiently. The $\alpha_{i}$ stands for the risk-adjusted excess return of an investment compared to its benchmark. Thus, $\alpha_{i}$ measures the part of the price development which can be explained by the selection of the share and not by the general market risk. The dependency of the stock on its benchmark is disengaged by $\beta_{i}$. It measures the sensitivity of a stock to changes in the overall market. The stochastic disturbance, $\varepsilon_{i}$, comprises all random fluctuations of a security. Due to the small influence of the disturbance, $\varepsilon_{i}$, on the overall result, the consideration of this can be neglected. The market return, $R_{m t}$, is represented by a benchmark index (Hackl, 2013). The market model has the structure shown in formula 2 :

$$
E\left(R_{i t}\right)=\alpha_{i}+\beta_{i} R_{m t}+\varepsilon_{i}
$$

Seasonal extensions are usually announced in the same month of each year. In order to avoid overlapping effects between the individual seasons, a shorter estimation period of 200 trading days is chosen in this paper. The event window is chosen based on Pauser's recommendation with 10 trading days before and after the event (Pauser, 2007). The event day is the reference point for the determination of the other time slots and denotes the "day 0 " $(t=0)$. All other points in time are labeled according to their timing relative to the event day.

The abnormal returns are calculated by taking the difference between the actual and expected daily returns of a security (Zureck, 2016).

$$
A R_{i t}=R_{i t}-E\left(R_{i t}\right)
$$

To verify that the abnormal returns calculated for the event period statistically deviate from zero, the simple t-test procedure is used. The procedure assumes that the abnormal returns are normal-distributed. However, the t-test behaves robustly with respect to deviations from the normal distribution (Hawliczek, 2008). The ttest examines the extent to which two empirically averaged values differ from each other. Correspondingly, the null hypothesis $\mathrm{HO}$ to be tested is that the abnormal return on a given day, ARit, is zero. The test statistic for a security $i$ on day $t$ is calculated as shown in formula 4 (Zureck, 2016):

$$
t_{A R i t}=\frac{A R_{i t}}{\sqrt{\frac{\sum_{t}^{t=-11}=-200}{200-m}\left(A R_{i t}-\overline{A R}\right) \cdot 2}}
$$

The statistical significance of the abnormal returns is checked individually for each event using the $p$-value. The $p$-value is used to check whether the null hypothesis can be rejected ( $p$-value $\leq$ significance level) or maintained ( $p$-value $\geq$ significance level). The $p$-value is calculated as shown in formula 5 . This is based on the assumption that the returns are normal-distributed with $n-p-1$, where $n$ is the 
length of the observation period and $p$ the number of explanatory variables in the regression (Zureck, 2016).

$$
p_{i t}=2 * \min \left[P\left(T_{n-p-1} \geq t_{\text {ARit }} \mid H_{0}\right), P\left(T_{n-p-1} \leq t_{\text {ARit }} \mid H_{0}\right)\right]
$$

In order to catch any rumors that may arise in the run up to the season extension, the accumulated abnormal returns for the event period are also examined. Furthermore, it also takes into account that the dissemination of the new information may take some time. Thus, upstream and downstream effects are taken into account around the time of the announcement (Pauser, 2007). The accumulated abnormal returns are calculated for the period $[-10 ; 10]$, based on the abnormal Ta yields as calculated in formula 6:

$$
C A R_{i t}=\sum_{t=1}^{n} A R_{i t}
$$

The review of statistical significance for accumulated abnormal returns is the same as for abnormal daily returns using $p$-values. The significance test is based on that for the abnormal returns and is calculated as shown in Formula 7 (Zureck, 2016):

$$
t_{C A R_{i t}}=\frac{C A R_{i t}}{\sqrt{\frac{\sum_{t=-200}^{t=-11}\left(A R_{i t}-\overline{A R}\right)^{2}}{200-m}}}
$$

\subsection{Data and Variables}

The relevant event in this investigation is the announcement of a season extension. Using the described method of an event study, a total of 33 events were defined and examined. The analyzed dataset contains 33 events in the form of announcements about scale extensions of eight different series. Table 2 gives an

\begin{tabular}{|c|c|c|c|c|}
\hline Company & Provider & Series & Season & Announcement day \\
\hline \multirow{3}{*}{$\begin{array}{c}\text { AMC } \\
\text { Networks }\end{array}$} & \multirow{3}{*}{ AMC } & \multirow{3}{*}{ Better Call Saul } & 2 & 20.06 .2014 \\
\hline & & & 3 & 15.03 .2016 \\
\hline & & & 4 & 27.07 .2017 \\
\hline \multirow{6}{*}{$\begin{array}{c}\text { AMC } \\
\text { Networks }\end{array}$} & \multirow{6}{*}{ AMC } & \multirow{6}{*}{$\begin{array}{c}\text { The Walking } \\
\text { Dead* }\end{array}$} & 4 & 21.12 .2012 \\
\hline & & & 5 & 29.10 .2013 \\
\hline & & & 6 & 07.10 .2014 \\
\hline & & & 7 & 30.10 .2015 \\
\hline & & & 8 & 17.10 .2016 \\
\hline & & & 9 & 13.01 .2018 \\
\hline \multirow{3}{*}{ Netflix } & \multirow{3}{*}{ Netflix } & \multirow{3}{*}{ House of Cards** } & 3 & 04.02 .2014 \\
\hline & & & 4 & 02.04 .2015 \\
\hline & & & 5 & 29.01 .2016 \\
\hline
\end{tabular}
overview of the investigated events.

Table 2 Overview of the Investigated Events 


\begin{tabular}{|c|c|c|c|c|}
\hline Company & Provider & Series & Season & Announcement day \\
\hline \multirow{2}{*}{ Netflix } & \multirow{2}{*}{ Netflix } & \multirow{2}{*}{ Narcos } & 2 & 03.09 .2015 \\
\hline & & & $3+4$ & 06.09 .2016 \\
\hline \multirow{4}{*}{ Netflix } & \multirow{4}{*}{ Netflix } & \multirow{4}{*}{$\begin{array}{l}\text { Orange is the } \\
\text { New Black }\end{array}$} & 2 & 27.06 .2013 \\
\hline & & & 3 & 05.05 .2014 \\
\hline & & & 4 & 15.04 .2015 \\
\hline & & & $5+6+7$ & 05.02 .2016 \\
\hline \multirow{2}{*}{ Netflix } & \multirow{2}{*}{ Netflix } & \multirow{2}{*}{ Stranger Things } & 2 & 31.08 .2016 \\
\hline & & & $3+4$ & 22.08 .2017 \\
\hline \multirow{6}{*}{$\begin{array}{l}\text { Time } \\
\text { Warner }\end{array}$} & \multirow{6}{*}{$\mathrm{HBO}$} & \multirow{6}{*}{$\begin{array}{l}\text { Game of } \\
\text { Thrones }\end{array}$} & 2 & 19.04 .2011 \\
\hline & & & 3 & 10.04 .2012 \\
\hline & & & 4 & 02.04 .2013 \\
\hline & & & $5+6$ & 08.04 .2014 \\
\hline & & & 7 & 22.04 .2016 \\
\hline & & & 8 & 04.01 .2018 \\
\hline \multirow{7}{*}{$\begin{array}{l}\text { 21st Century } \\
\text { Fox }\end{array}$} & \multirow{7}{*}{ FX Networks } & \multirow{7}{*}{$\begin{array}{c}\text { American } \\
\text { Horror Story*** }\end{array}$} & 2 & 31.10 .2011 \\
\hline & & & 3 & 15.11 .2012 \\
\hline & & & 4 & 06.11 .2013 \\
\hline & & & 5 & 13.10 .2014 \\
\hline & & & 6 & 11.11 .2015 \\
\hline & & & 7 & 04.10 .2016 \\
\hline & & & $8+9$ & 12.01 .2017 \\
\hline & 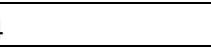 & 8 & & 33 \\
\hline \multicolumn{5}{|c|}{$\begin{array}{l}\text { * There was no analysis of squadron } 2-3 \text {, since AMC Networks is only listed since } \\
06 / 2011 . \\
* * \text { There was no analysis of Season 2, as Netflix announced this together with Season } 1 . \\
* * * \text { FX Network was sold to Disney after the analyzed period. }\end{array}$} \\
\hline
\end{tabular}

Source: Authors' own representation.

The first investigated announcement took place on 19.04.2011 with Season 2 of Game of Thrones. The latest investigated announcement took place on 13.01.2018 with The Walking Dead Season 9. On average, the series examined contain 11.91 episodes per season. The eighth season of Game of Thrones contains the fewest episodes (6) and the entire series The Walking Dead with 16 episodes per season contains the most. The average total duration of the seasons studied is 494.53 minutes. The shortest season with a total running time of 400 minutes is American Horror Story Season 6 and the longest with 797 minutes is the seventh season of The Walking Dead.

The basis for the 33 analyzed announcements of scale extensions are four providers and eight series. Investigations were made from Season 2 of the respective series. Viewers will become fans during the first season of a series. Accordingly, the emotional attachment to a series is built up in the course of each first season. As part of a study based on its own algorithms, Netflix was able to analyze exactly which episode of the first season binds viewers to it. The binding episode was defined based on which at least $70 \%$ of the audience saw the entire season to the 
end (Heise online, 2015 and Netflix Media-Center 2016). The analyzed events are in the period from 19.04.2011 to 13.01.2018. Further announcements regarding scale extensions of the investigated series after this period are not considered. In addition, only events that took place after the initial public offering of the respective provider were examined.

The announcement day of a season extension was largely determined by the series portal Serienjunkies.de. Some event days have been verified using media reports and reports on the providers' websites. Serienjunkies.de is a German specialist portal for successful TV series, with a focus on American TV series. In addition to up-to-the-minute news, the industry service also provides content, recessions, start dates and background information on various series (Serienjunkies, 2018). 32 announcements were made on trading days. One announcement was made over the weekend. In this case, the next trading day was used as the event day.

The stock prices and the market index come from the financial information service Bloomberg. The recognized Bloomberg database is used in many scientific analyzes related to the capital market and provides well-founded capital market data (Zureck, 2016). In order to calculate the returns, closing prices were used which are already adjusted for dividend distributions and capital measures (e.g. capital increases, share splits). The market index used was the S \& P 500. It is considered an indicator of the development of the entire US stock market. Three of the four companies are included in the S \& P 500. Since the influence of the three companies on the entire index is too small, it is justifiable not to adjust this to the companies investigated (Finanzen.net, 2018).

\section{Results and Discussion}

Table 3 gives an overview of the test results, the number of significant $p$-values for the entire event period $[-10 ; 10]$, the event window before the announcement [$10 ; 1]$, the announcement day [0] and the event window from the announcement $[0 ; 10]$. The test was carried out at the usual significance levels of ten, five and one percent (Fahrmeir et al. 2016). In addition, it indicates how many announcements regarding season extensions of the respective series were examined.

Table 3 Number of Significant Results for the Returns

\begin{tabular}{|c|c|c|c|c|c|c|}
\hline \multirow[b]{2}{*}{ Series } & \multirow[b]{2}{*}{$\begin{array}{c}\text { Investigated } \\
\text { Announce- } \\
\text { ments } \\
\end{array}$} & \multicolumn{5}{|c|}{ p-values, returns } \\
\hline & & $\begin{array}{c}\text { Level of } \\
\text { significan } \\
\text { ce } \\
\end{array}$ & {$[-10 ; 10]$} & {$[-10 ; 1]$} & [0] & {$[0 ; 10]$} \\
\hline \multirow{3}{*}{$\begin{array}{c}\text { Better Call } \\
\text { Saul }\end{array}$} & \multirow{3}{*}{3} & $10 \%$ & 2 & 2 & 3 & 3 \\
\hline & & $5 \%$ & 2 & 2 & 3 & 2 \\
\hline & & $1 \%$ & 2 & 2 & 3 & 2 \\
\hline \multirow{2}{*}{$\begin{array}{c}\text { The } \\
\text { Walking }\end{array}$} & \multirow{2}{*}{6} & $10 \%$ & 4 & 5 & 5 & 3 \\
\hline & & $5 \%$ & 4 & 4 & 5 & 3 \\
\hline
\end{tabular}




\begin{tabular}{|c|c|c|c|c|c|c|}
\hline \multirow[b]{2}{*}{ Series } & \multirow[b]{2}{*}{$\begin{array}{c}\text { Investigated } \\
\text { Announce- } \\
\text { ments }\end{array}$} & \multicolumn{5}{|c|}{ p-values, returns } \\
\hline & & $\begin{array}{c}\text { Level of } \\
\text { significan } \\
\text { ce } \\
\end{array}$ & {$[-10 ; 10]$} & {$[-10 ; 1]$} & [0] & {$[0 ; 10]$} \\
\hline Dead & & $1 \%$ & 4 & 2 & 3 & 3 \\
\hline \multirow{3}{*}{$\begin{array}{c}\text { House of } \\
\text { Cards }\end{array}$} & \multirow{3}{*}{3} & $10 \%$ & 3 & 3 & 1 & 3 \\
\hline & & $5 \%$ & 3 & 3 & 1 & 3 \\
\hline & & $1 \%$ & 3 & 2 & 1 & 3 \\
\hline \multirow{3}{*}{ Narcos } & \multirow{3}{*}{2} & $10 \%$ & 2 & 2 & 2 & 2 \\
\hline & & $5 \%$ & 2 & 2 & 2 & 2 \\
\hline & & $1 \%$ & 2 & 2 & 2 & 2 \\
\hline \multirow{3}{*}{$\begin{array}{l}\text { Orange is } \\
\text { the new } \\
\text { Black }\end{array}$} & \multirow{3}{*}{4} & $10 \%$ & 4 & 4 & 2 & 3 \\
\hline & & $5 \%$ & 4 & 4 & 1 & 3 \\
\hline & & $1 \%$ & 3 & 0 & 1 & 3 \\
\hline \multirow{3}{*}{$\begin{array}{l}\text { Stranger } \\
\text { Things }\end{array}$} & \multirow{3}{*}{2} & $10 \%$ & 2 & 2 & 1 & 2 \\
\hline & & $5 \%$ & 2 & 2 & 1 & 2 \\
\hline & & $1 \%$ & 2 & 2 & 0 & 2 \\
\hline \multirow{3}{*}{$\begin{array}{l}\text { Game of } \\
\text { Thrones }\end{array}$} & \multirow{3}{*}{6} & $10 \%$ & 6 & 5 & 5 & 5 \\
\hline & & $5 \%$ & 6 & 5 & 4 & 5 \\
\hline & & $1 \%$ & 5 & 2 & 3 & 5 \\
\hline \multirow{3}{*}{$\begin{array}{c}\text { American } \\
\text { Horror } \\
\text { Story } \\
\end{array}$} & \multirow{3}{*}{7} & $10 \%$ & 6 & 5 & 7 & 7 \\
\hline & & $5 \%$ & 6 & 4 & 5 & 7 \\
\hline & & $1 \%$ & 6 & 3 & 5 & 4 \\
\hline \multirow{3}{*}{$\begin{array}{l}\text { cumu- } \\
\text { lated }\end{array}$} & \multirow{3}{*}{33} & $10 \%$ & 29 & 28 & 26 & 28 \\
\hline & & $5 \%$ & 29 & 26 & 22 & 27 \\
\hline & & $1 \%$ & 27 & 15 & 18 & 24 \\
\hline
\end{tabular}

Source: Authors' own representation.

First of all, there are significant results for all event periods and the announcement day. The absolute number of significant events is consistently the highest at a ten percent level of significance. Furthermore, a significant number of significant values can be detected at the other two significance levels. For the entire event period, 27 significant values can be detected at a significance level of one percent, which corresponds to $81.82 \%$. In all series except Better Call Saul, The Walking Dead and American Horror Story, announcements for all seasons are significant at a ten percent level of significance for the entire event window. For the series House of Cards, Narcos and Stranger Things, the announcements for all reviewed seasons for the entire event period are still significant at a significance level of one percent. The announcement day is significant for all reviewed seasons of the series Better Call Saul and Narcos at the lowest level of significance. Each scale extension being scored is significant in at least one of the scored event windows or the announcement day at a ten percent level of significance. For eight seasons, each announcement day and every event window examined is significant at one percent significance level. In summary, there is a sufficiently large number of significant 
results to confirm hypothesis $\mathrm{H} 1$. Investors react to the announcement of a scale extension with a change in investment behavior.

Furthermore, it was examined whether a positive or negative abnormal return could be achieved in the mentioned event windows and on the announcement day. The results are shown in Table 4.

Both positive and negative absolute significant returns can be proven for all event windows and the announcement day. In the entire event window, $54.54 \%$ of the returns are positive, $33.33 \%$ are negative and $12 \%$ are not significant. In the event window from the day of the announcement, almost half of the returns are positively significant and one third are negatively significant. On the announcement day and in the event window before the announcement, the negative significant returns are likely to predominate. However, it cannot generally be deduced how investors react from the results available. Therefore, hypothesis $\mathrm{H} 2$ can neither be confirmed nor rejected.

Table 4 Absolute Returns

\begin{tabular}{|c|c|c|c|c|c|}
\hline \multirow[b]{2}{*}{ Series } & \multirow[b]{2}{*}{ Season } & \multicolumn{4}{|c|}{ Absolute returns in \% } \\
\hline & & {$[-10 ; 10]$} & {$[-10 ; 1]$} & [0] & {$[0 ; 10]$} \\
\hline \multirow{3}{*}{ Better Call Saul } & 2 & 1.74 & 2.57 & $-2.24 * * *$ & $-0.81 *$ \\
\hline & 3 & $-10.60 * * *$ & $-3.83 * * *$ & $-4.32 * * *$ & $-6.79 * * *$ \\
\hline & 4 & $11.63 * * *$ & $20.11 * * *$ & $6.78 * * *$ & $-5.39 * * *$ \\
\hline \multirow{6}{*}{$\begin{array}{c}\text { The Walking } \\
\text { Dead }\end{array}$} & 4 & $-10.92 * * *$ & $-15.86 * * *$ & $2.95 * * *$ & $5.13 * * *$ \\
\hline & 5 & -7.39 & $1.14^{* *}$ & $-1.33 * *$ & -8.59 \\
\hline & 6 & $6.01 * * *$ & $-5.94 *$ & $0.77 * *$ & 12.33 \\
\hline & 7 & $-3.71 * * *$ & $-8.42 * *$ & -0.11 & $4.36 * * *$ \\
\hline & 8 & 1.68 & -5.34 & $2.42 * * *$ & 7.14 \\
\hline & 9 & $-14.05 * * *$ & $-11.24 * * *$ & $-2.23 * * *$ & $-2.85 * * *$ \\
\hline \multirow{3}{*}{ House of Cards } & 3 & $37.36 * * *$ & $44.70 * * *$ & -1.38 & $-4.76 * * *$ \\
\hline & 4 & $50.66 * * *$ & $1.00 * * *$ & -0.28 & $47.37 * * *$ \\
\hline & 5 & $-26.81 * * *$ & $-15.67 * *$ & $-7.10 * * *$ & $-10.72 * * *$ \\
\hline \multirow{2}{*}{ Narcos } & 2 & $-17.21 * * *$ & $-9.70 * * *$ & $-4.70 * * *$ & $-7.37 * * *$ \\
\hline & $3+4$ & $7.36 * * *$ & $2.81 * * *$ & $2.42 * * *$ & $4.54 * * *$ \\
\hline \multirow{4}{*}{$\begin{array}{l}\text { Orange is } \\
\text { the new Black }\end{array}$} & 2 & $20.36 * *$ & $-7.69 * *$ & 0.70 & 27.21 \\
\hline & 3 & $2.34 * * *$ & $-8.07 * *$ & 1.48 & $10.33 * * *$ \\
\hline & 4 & $39.90 * * *$ & $19.80 * *$ & $-1.89 *$ & $20.27 * * *$ \\
\hline & $5+6+7$ & $-25.48 * * *$ & $-21.09 * *$ & $-7.05 * * *$ & $-3.79 * * *$ \\
\hline \multirow{2}{*}{ Stranger Things } & 2 & $6.05 * * *$ & $3.45 * * *$ & $0.41 * *$ & $2.61 * * *$ \\
\hline & $3+4$ & $-1.47 * * *$ & $-3.88 * * *$ & 0.08 & $2.39 * * *$ \\
\hline \multirow{5}{*}{$\begin{array}{l}\text { Game of } \\
\text { Thrones }\end{array}$} & 2 & $7.59 * * *$ & $8.71 * * *$ & $-1.61 * *$ & $-0.96 * * *$ \\
\hline & 3 & $0.67 * * *$ & $-5.35 * *$ & 0.29 & $6.17 * * *$ \\
\hline & 4 & $1.32 * *$ & $-0.43 * * *$ & $-1.40 * * *$ & 1.72 \\
\hline & $5+6$ & $0.10 * * *$ & 0.03 & $0.51 *$ & $0.07 * * *$ \\
\hline & 7 & $4.84 * * *$ & $2.92 * *$ & $2.23 * * *$ & $1.93 * * *$ \\
\hline
\end{tabular}




\begin{tabular}{|c|c|c|c|c|c|}
\hline \multirow[b]{2}{*}{ Series } & \multirow[b]{2}{*}{ Season } & \multicolumn{4}{|c|}{ Absolute returns in \% } \\
\hline & & {$[-10 ; 10]$} & {$[-10 ; 1]$} & [0] & {$[0 ; 10]$} \\
\hline & 8 & $3.83 * * *$ & $2.38 * *$ & $1.23 * * *$ & $1.45 * * *$ \\
\hline \multirow{7}{*}{$\begin{array}{c}\text { American } \\
\text { Horror Story }\end{array}$} & 2 & $-23.60 * * *$ & $-17.95 * * *$ & $14.05^{* * *}$ & $-5.69 * *$ \\
\hline & 3 & $7.63 * * *$ & $13.32 * *$ & $-7.87 * * *$ & $-5.69 * *$ \\
\hline & 4 & $-28.83 * * *$ & $-12.16 * * *$ & $-2.76 * * *$ & $-16.71 * * *$ \\
\hline & 5 & $-2.03 * * *$ & -6.87 & $-1.19 *$ & $5.02 * *$ \\
\hline & 6 & 1.00 & 0.04 & $1.38 *$ & $0.96 * * *$ \\
\hline & 7 & $22.73 * * *$ & $14.28 *$ & $2.57 * * *$ & $8.49 * * *$ \\
\hline & $8+9$ & $36.33 * * *$ & $21.32 * * *$ & $-3.17 * * *$ & $15.20 * * *$ \\
\hline
\end{tabular}

Source: Authors' own representation.

The announcements of the second seasons of the respective series also show a differentiated picture. Only in the case of the Stranger Things series, positive returns can be demonstrated for all three event windows and the announcement day. For the second season of Narcos, there are negative significant returns for all three event screens and the day of the announcement. The announcement of the second season's production of American Horror Story resulted in a negative significant return of $-23.60 \%$ for the entire event window. Finally, hypothesis $\mathrm{H} 3$ is rejected.

With regard to the entire investigation, the highest positive absolute returns have been found for the series House of Cards. The third-season announcement event window has an absolute return of $37.36 \%$ for a one percent significance level and $50.66 \%$ for the fourth season. The highest negative significant return to one percent of significance is $-\mathbf{2 8 . 8 3 \%}$, the fourth season of American Horror Story. The lowest positive significant returns were found in the Game of Thrones series. Announcing the fifth- and sixth-season extension of the series reveals an absolute return of $0.10 \%$ for a one-percent significance level for the entire event window and $0.07 \%$ for the event window from the announcement day.

\section{Conclusions}

In this study, series are understood as a commodity, which has a great similarity to movies. The film industry has been described and analyzed in numerous studies so far. It offers a multitude of interesting problems for economic consideration and high availability of data. From the initial concept of an idea to the production, distribution and publishing, there are many aspects of a single film project and the film industry as a whole that have already been explored (see McKenzie 2009, p.1). The findings from the film industry can be partially transferred to series.

Films and series have some similarities. Both are produced and partially marketed by the same companies. The production is carried out in cost-intensive large-scale 
projects, all of which have an uncertainty regarding the eventual success (see De Vany \& Walls 1999, pp. 26-28). However, in contrast to films, series are able to build a much deeper emotional connection with the recipients because of the serial narrative structure, the realistic characters, and the ability to present actions in more detail.

The central question of this paper builds on the theoretical findings. It is examined whether an announcement of a series extension demonstrably influences the share price of the respective supplier. To this end, three hypotheses are set up and reviewed by means of an event study. The first hypothesis can be confirmed because of the significant amount of significant results. The study results show that extending a series leads to a change in investors' investment behavior in relation to the stock of the provider. The uniqueness of the series and films together leads us to believe that investors are more likely to respond to uncertain large-scale projects by reducing their shares. This assumption was further supported by the generally limited ability of the market to properly estimate projects from the film industry in advance. Based on these findings, the second hypothesis was formulated that shareholders respond to the announcement of staggered prolongations with a reduction of their shares. The detailed analysis shows that although there are many similarities between films and series, the absolute returns for series are not entirely negative. This is justified by the fact that series providers, in contrast to film studios, have established their channels as real brands. Furthermore, due to the high quality of the series and the associated strong connection, investors have a rather positive expectation of the future when it comes to the continuation of a series. The second hypothesis can thus neither be confirmed nor rejected. The starting point for the last hypothesis is the realization that investors build the emotional bond with a series as they receive the first season. From this, the third hypothesis was derived that the announcement of the respective second season of a series has a positive significant influence on the yield development of the respective provider. Again, the present results show a differentiated picture, which is why this hypothesis is finally rejected. In summary, however, it can be stated that shareholders build a greater emotional bond to series than to films.

\section{References}

Bock, A. (2013). Fernsehserienrezeption, Produktion, Vermarktung und Rezeption US-amerikanischer Prime-Time-Serien. Wiesbaden: Springer Fachmedien.

bitkom (2018). Zwei von fünf Internetnutzern bezahlen für Serien und Filme. Retrieved from: https://www.bitkom.org/Presse/Presseinformation/Zwei-vonfuenf-Internetnutzern-bezahlen-fuer-Serien-und-Filme.html.

De Vany, A., Walls, W. D. (1999). Uncertainty in the Movie Industry: Does Star Power Reduce the Terror of the Box Office. Journal of Cultural Economics, vol.23(4), pp. 285-318. 
Dördrechter, N. (2006). Piraterie in der Filmindustrie, Eine Analyse der Gründe für Filmpiraterie und deren Auswirkungen auf das Konsumverhalten. Wiesbaden: Deutscher Universitäts-Verlag/GWV Fachverlage GmbH (Dissertation).

Elberse, A. (2007). The Power of Stars: Do Star Actors Drive the Success of Movies? Journal of Marketing, vol. 71 (October 2007), pp. 102-120.

Einav, L., Ravid, S. A. (2009). Stock market response to changes in movies' opening dates. Journal of Cultural Economics, vol. 33(4), pp. 311-319.

Fahrmeir, L., Heumann, C., Künstler, R., Pigeot, I., Tutz, G. (2016). Statistik, Der Weg zur Datenanalyse (8th ed.). Berlin, Heidelberg: Springer Spektrum.

Finanzen.net (2018). S\&P 500. Retrieved from: https://www.finanzen.net/index/S\&P_500.

Hackl, P. (2013). Einführung in die Ökonometrie (2nd ed.). München: Pearson.

Hawliczek, J. W. (2008). Kapitalmarktfaktor Moral?, Kursimplikation ethisch relevanter Aspekte auf dem Kapitalmarkt. Wiesbaden: Gabler.

Heise online (2015). Netflix-Studie über Serien: Wann Zuschauer zu Fans werden. Retrieved from: https://www.heise.de/newsticker/meldung/Netflix-Studie-ueberSerien-Wann-Zuschauer-zu-Fans-werden-2824277.html.

McKenzie, J. (2012). The Economics of Movies: A Literature Survey. Journal of economic surveys, vol. 26(1), pp.42-70.

Netflix Medien-Center (2016). Immer noch angefixt und Netflix weiß warum, Netflix enthüllt in einer neuen Untersuchung, wann Zuschauer auf der ganzen Welt Serien wie The Get Down, Narcos, Stranger Things und vielen mehr verfallen. Retrieved from: https://media.netflix.com/de/press-releases/youre-still-hooked-andnetflix-knows-why.

Nitzschke, T. (2005). Präferenzmessung in der Online Medien-Distribution: Sharing-Verhalten und individuelle Zahlungsbereitschaft für Filme im Internet. Wiesbaden: Deutscher Universitäts-Verlag/GWV Fachverlage GmbH.

Pauser, S. H. (2007). M\&A in der Bauindustrie, Werteffekte und Erfolgsdeterminanten. Wiesbaden: Deutscher Universitäts-Verlag.

Serienjunkies (2018). Hilfe zum Serienportal Serien-junkies.de. Retrieved from: https://www.serienjunkies.de/docs/faq.html.

Schlütz, D. (2016). Quality-TV als Unterhaltungsphänomen, Entwicklung, Charakteristika, Nutzung und Rezeption von Fernsehserien wie The Sopranos, The Wire oder Breaking Bad, Wiesbaden: Springer Fachmedien. 
Zureck, A. (2016). Eine kapitalmarktorientierte Analyse der Ökonomisierung des Fußballs im Kontext der Behavioral Finance. Retrieved from: https://is.muni.cz/th/e5nlc/Doktorarbeit. 